\section{FORTHCOMING EVENTS}

(Meetings marked with an asterisk * are open to the public)

\section{Monday, May 28}

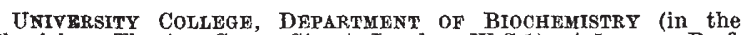
Physiology Theatre, Gower Street, London, W.C.1), at 5 p.m.-Prof. R. K. Morton (University of Adelaide): "The Flavohæmoprotein ytochrome $b_{\mathbf{2}}-$-a New Type of Dehydrogenase".

UNIVERSITY OF LONDON (at the Wright-Fleming Institute of Microbiology, St. Mary's Hospital Medical School, Paddington, London, W.2), at 5 p.m.-Prof. E. S. Lennox (New York): "Antiof four AImroth Wright Lectures.)

BRITISH SOCIETY FOR THE PHILOSOPHY OF SCIENOE (in the Joint Staff Common Room, University College, Gower Street, London, Chemistry".

ROYAL GEOGRAPHICAL SOCIETY (at 1 Kensington Gore, London, S.W.7), at 8.30 p.m. -Mr. Owen Lattimore: "The Geography of Ghengis Khan" (The Dickson Asia Lecture).

Monday, May 28-Saturday, June 2

FoURTH INTERNational INSTRUMENTS, Fliectronics aNd AUTOMATION EXHIBITION (at Olympia, London).*

\section{Tuesday, May 29}

UNIVRRSITY of LONDON (in the Physics Lecture Theatre No. 2 , Imperial College of Science and Technology, Prince Consort Road, Caen): "On Some Problems of Harmonic Analysis".*

Tuesday, May 29-Wednesday, May 30

Institution of Mechanidal Eingineers (at 1 Birdcage Walk, Westminster, London, S.W.1), at $6 \mathrm{p.m}$. on Tuesday and $10 \mathrm{a.m}$ on Wednesday-Informal Discussion on "Machine Tools and Automatic Control--Technical and Economic Appraisal".

\section{Wednesday, May 30}

BRITISH NUCLRAR ENERGY Societry (at 1-7 Great George Street, London, S.W.1), at 5.30 p.m.--Sir Roger Makins: "Nuclear PowerYear of Promise"

\section{Thursday, May 31}

ROYal Societr (at Burlington House, Piccadilly, London, W.1) at 4.30 p.m. - Mr. D. Michie and Mr. M. F. A. Woodruff: "Induction of Specific Immunological Tolerance of Homografts in Adult Mice by Sublethal Irradiation and Injection of Donor Type Spleen Cells mectomy on the Immunological Responsiveness of the Mouse".

Sochety of Chemcas, Industry, Plastics and Polymgr Grotp (at the Film Theatre, Shell Mex House, Strand, London, W.C.2), at 6 p.m.-Annual General Meeting.

Polarographic Society (in the Optics Lecture Theatre of the New Physics Building, Imperial College of Science and Technology, London, S.W.7), at 7 p.m.- Papers on "Polarographic Analysis in Organic Systems",

Thursday, May 31 -Thursday, June 7

Institution of EleCtrical ENGINEERS, ELECTRONICS AND COMMUNICATIONS SECTION (in association with the TELEVISION SocIETY, at the Institution of Electrical Engineers, Savoy Place, London, W.C.2)-International Television Conference.

\section{Friday, June 1}

Roxar Institution (at 21 Albemarle Street, London, W.1), at 9 p.m.-Mr. G. Bennett: "The Biology of the Astronaut".

\section{Monday, June 4}

UNIVERSITY OF LONDON (at the London Hospital Medical College, Turner Street, London, E.1), at 5.15 p.m.- Prof. F. Halberg (Univerin or Minnesota

\section{Monday, June 4 -.-Thursday, June 7}

British Filectrical Power Convention (at The Dome, Brighton Fourteenth Annual Meeting. Theme-"The British Electrical Industry in the World Scene",

\section{APPOINTMENTS VACANT}

AppuICations are invited for the following appointments on or before the dates mentioned:

LECTURER IN SOCTOLOGY-The Registrar, The University, Leiceste (June 2.)

ASSISTANT LECTURER; an EXPERIMENTAL OFFICER (preferably graduate in physics or electrical engineering, or qualified in electronics) to take charge of the electronic equipment; and a RESEARCF of PHYSICs-The Registrar, The University, Leicester (June 2)
ASSISTANT LECTURER and a TUTORIAL ASSistant IN SOCIOLOQY-he Registrar, The University, Leicester (June 2).

Liw tary, The University, dinburgh (June 4).

ASSISTANT LECTURER (preferably with qualifications in social The Registrar, The University, Sheffield

LECTURER (preferably with African field experience and interested in the geography of soils and the conservation of resources) IN THE PHYSICAL GEOGRAYY TF INTERT The University, Edinburgh AND CA

SENIOR TUTOR (with a degree and preferably teaching experience) IN THE SCHOOL OF MATHEMATICS, University of New South WalesAgent-General for New South Wales, 56-57 Strand, London, W.C.2; and the Appointments Section, The University of New South Wales, Box 1, Post Office, Kensington, New South Wales, Australia (June 8). EXPERIMENTAL OFFICER OF SENIOR EXPERIMENTAL OFFICER IN THE DEPARTMENT OF MECHANICS OF FLOIDS, for duties which will include the design and construction of electronic and optical apparatus for studying turbulence, aerodynamic noise and flows at very high speeds, including their interaction with magne

LECTURERS (2) IN THE DFPARTMENT OF MATHEMATICS-The Secretary, The University, Edinburgh (June 9).

SCIENTIFIC OFFICER (male, with a good honours degree), to engage in research on sugar beet breeding, with special reference to the exploitation of male sterility and polyploidy- The Secretary, Plant eeding Institu, Trump

University- The Secretary cssociation of Universities of at Monash niversity-The Secretary, Association of Universities of the British Commonwealth (Branch Office), Marlborough House, Pall Mall London, S. W.1 or The Registrar, Monas

DEMONSTRATOR (with, or about to obtain a good honours degree) IN PHYSICS-The Registrar, The University, Keele, Staffs (June 15) PRYSICS-The Registrar, The University, Keele, staffs (June 15) the fleld of magnetic resonance or microwave techniques) IN THF DEPARTMENT OF PHYSICS-The Registrar, The University, Keele, Staffs (June 15).

LECXURER IN GEOGRAPHy at Fourah Bay College, University College of Sierra Leone-The Secretary, Inter-University Council for Higher Education Overseas, 29 Woburn Square, Iondon, W.C.1 (June 15).

LECTURER (with an honours degree in botany and postgraduate experience in taxonomic work) IN THE DEPARTMENT OF BOTANY, University of Ife, Nigeria-The Secretary, Inter-University Counci for Higher Education Overseas, 29 Woburn Square, London, W.C.1 (June 19).

LeCturer or Assistant LeCruRer in Physios at the Royal University of Malta-The Secretary, Inter-University Council for Higher Education Overseas, 29 Woburn Square, London, W.C.1 June 28).

RESARCH Fellow IN THE SURFACE PHYSICS GROUP, to join a tary and Registrar, The University, Southampton (June 30).

CHAIR OF PHYSICs in the University of Western Australia-The Secretary, Association of Universities of the British Commonwealth (Australia and London, July 7).

ASSISTANT LECTURER IN AGRIOULTURAL ECONOMICS AND FARM MANAGEMENT; and an ASSISTANT LECTURER IN ANIMAI HUSBANDRY -Clerk to the Governors, Essex Institute of Agriculture, Writtle, Chelmsford, Essex.

LECTORER or DEMONSTRATOR IN GENETICS, with special reference to cytology-Dr. C. B. Groodhart, Museum of Zoology, The University, Downing Street, Cambridge.

MASTER TO TEACH BIOLOGY in VI form to A level; also GeNeral ScIENCE AND/OR MATHEMATICS in Middle School-The Headmaster, King's School, Rochester, Kent.

RESEarCh Assistant IN ORganic Chemistry-The Secretary, Birkbeck College (University of London), Malet Street, London, W.C.1.

\section{REPORTS and other PUBLICATIONS (not included in the monthly Books Supplement)}

Great Britain and Ireland

National Union of Teachers. Ascertainment of Educationally Subnormal Children: Report prepared by the Advisory Committee fo Special Schools. Pp. 8. (London: National Union of Teachers, 1962.)

Agricultural Research Council : Ditton and Covent Garden Laboratories. Annual Reports, 1959 and 1960. Pp. 47. (Maidstone : Agri[23 ithe The Council for Nature, 1962.) 2s,6d. [23 The Royal College of Science and Technology, Glasgow. Courses of Postgraduate Study. Pp. 27. (Glasgow : Royal College of Science and Technology, 1962.)
[23 Lundy Field Society. Thirteenth Report, 1959/1960. Pp. 82. (Barnstable: John C. A. Dyke, Secretary, Lundy Field Society, 8 Rock Avenue, 1962.) A. Dyke, Secretary, Lundy Fid Society,
[23 Annual Report of the National Oceanographic Council, 1 April 1960-31 March 1961. Pp. v+41 6 plates. (Cambridge: At the The Carnegie Trust for the Universities of Scotland. Sixtieth Annual Report for the year 1960-61. Pp. vi 68 . (Edinburgh : Carnegie Trust for the Universities of Scotland, 1962.) Laboratory. Notes on Applied Science, No. 28: The Measurement 